\title{
The character of transformation of the threats to Russia's energy security as the basis for evaluating the possibilities to meet the prospective demand for primary energy resources
}

\author{
Sergey Senderov ${ }^{1,2, *}$, Viktor Rabchuk ${ }^{l}$ \\ ${ }^{1}$ Melentiev Energy Systems Institute of Siberian Branch of the Russian Academy of Sciences, 130 Lermontov str., Irkutsk, Russia \\ ${ }^{2}$ Federal State Budget Educational Institution of Higher Education «Irkutsk National Research Technical University», 83 Lermontov str., \\ Irkutsk, Russia
}

\begin{abstract}
The paper analyses the situation with ensuring energy security in Russia over the past five years and provides an assessment of the nature of the transformation of the most significant threats to Russia's energy security until 2030. It is shown that by 2030 the annual potential of fuel and fuel in the country Energy complex for the production of primary fuel and energy resources together with the import of fuel and energy to Russia will significantly exceed its domestic needs. At the same time, the ability to export Russian natural gas could be significantly reduced. The paper shows that the situation with the decline in opportunities for the production and export of natural gas in Russia is not very encouraging. There are no prerequisites for a significant increase in world prices for hydrocarbons until 2030. And at the same time, there is a constant increase in the cost of oil and gas production and transportation on average across Russia. The paper concludes that the possibilities for the development of the Russian economy through the sale of only natural resources are practically exhausted by now.
\end{abstract}

\section{Introduction}

The paper assesses the potential situation with the fulfillment of the most important requirement of energy security (ES) of Russia - reliable provision of domestic demand for primary fuel and energy resources (FER) [1], taking into account the need to export Russian gas until 2035. The need to assess the potential volumes of such exports is due, on the one hand, to a noticeable increase in the cost of Russian gas due to a drop in production levels in old regions and the need to enter new regions with significantly higher unit costs for their development, and on the other hand, a significant decrease in world gas prices (USD $100 /$ thousand $\mathrm{m}^{3}$ in January 2020 (even before the COVID-19 pandemic) with a further decrease [2]) in the absence of prerequisites for a significant increase in these prices in the period up to 2035 . In addition, one has to take into account some uncertainty regarding recoverable gas reserves in new fields from which export was planned to the east (Chayandinskoye oil and gas condensate and Kovykta gas condensate fields [3, 4, etc.]).

It is proposed to forecast the situation with the fulfillment of the specified ES requirements on the basis of an assessment of the potential production capabilities of the Russia's energy industries in the period up to 2035. For this, it is initially required to assess the expected nature of the transformation of the most significant threats to the Russia's ES. The general research procedure is as follows:
- analyzed the analyzed period until 2035 is divided into three time periods: $2020-2025 ; 2026-2030$ and 2031-2035;

- at each time interval, the most significant emergency threats are selected and the nature of their transformation is assessed;

- the expected capabilities for the production of primary FER are formed by reference years. This is done on the basis of the results of assessing the character of the threats transformation and taking into account the retrospective indicators of the functioning of the Russian fuel energy complex (FEC);

- possible volumes of Russian natural gas export are determined. These volumes are determined by comparing the values of the expected demand for primary FER and the possibilities of their production, taking into account imports.

\section{The main threats to Russia's ES for analyzing the character of their transformation}

When choosing the threats to consider in the period until 2025, we will take into account the results of the functioning of the energy industries in Russia in previous years (Table 1), as well as the expected features of the functioning of these industries in the period until 2025.

* Corresponding author: ssm@isem.irk.ru 
Table 1. Russia's FEC in 2014-2019 [5-8].

\begin{tabular}{|c|c|c|c|c|}
\hline Index & 2014 & 2016 & 2018 & 2019 \\
\hline $\begin{array}{c}\text { Production of primary FER, } \\
\text { mln tce, incl. }\end{array}$ & 1863 & 1931 & 2032 & 2083 \\
\hline natural and assoc, gas, bcm & 642 & 653 & 725 & 737 \\
\hline oil and gas condensate, mln $t$ & 527 & 547 & 556 & 560 \\
\hline coal, mln $t$ & 359 & 383 & 401 & 397 \\
\hline $\begin{array}{c}\text { hydro and nuclear power } \\
\text { other FER, } \text { total, } \text { mln tce }\end{array}$ & 149 & 158 & 160 & 162 \\
\hline Import of FER, mln tce, incl. & 33 & 29 & 27 & 23 \\
\hline natural gas, bcm & 12 & 12 & 9 & 8 \\
\hline Total (income), mln tce, incl. & 1896 & 1960 & 2059 & 2106 \\
\hline natural gas, bcm & 654 & 665 & 734 & 745 \\
\hline $\begin{array}{c}\text { Domestic consumption of } \\
\text { primary FER, mln tce, incl. }\end{array}$ & 1034 & 1062 & 1092 & 1057 \\
\hline $\begin{array}{c}\text { natural and assoc. gas, bcm } \\
\text { Share of gas in domestic } \\
\text { consumpt. of primary FER, } \%\end{array}$ & 455 & 471 & 494 & 469 \\
\hline $\begin{array}{c}\text { oil used directly and oil } \\
\text { products total, } \text { mln tce }\end{array}$ & 229 & 234 & 231 & 228 \\
\hline coal, mln $t$ & 228 & 223 & 205 & 191 \\
\hline $\begin{array}{c}\text { hydro and nuclear power } \\
\text { other FER, } \text { total, } \text { mln tce }\end{array}$ & 149 & 158 & 160 & 162 \\
\hline Export of FER, mln tce, incl. & 862 & 898 & 967 & 1049 \\
\hline natural gas, bcm & 187 & 194 & 247 & 276 \\
\hline
\end{tabular}

* fuel burned at condensing stations to produce the same volumes of electricity

According to the data in Table 1, since 2014, the production of FER has grown noticeably - mainly due to the growth in hydrocarbon production. At the same time, the maximum possible levels of their production and export corresponded to the period of decline in world prices. In 2019, the price of gas reached $\$ 120$ $140 / \mathrm{mmcm}$, and oil - \$50-55/barrel (for comparison, the average world price of oil in 2012 was $\$ 110 /$ barrel, and gas price $\$ 400 / \mathrm{mmcm})[1,9]$. Revenues from the export of hydrocarbons with a decrease in world prices for them had to be obtained by increasing the volume of their sales. The low gas price prompted the importing countries to buy this gas for future use, filling all underground gas storage facilities and creating the preconditions for reducing the price for it in 2020 . Winter 2018 in the European part of Russia was somewhat colder than the last winters, this fact led to a decrease in natural gas consumption in 2019 compared to 2018 to the average values of recent years. As for coal, electricity generated at hydroelectric power plants and nuclear power plants, and other FER, then from 2016 to 2019 their annual production volumes remained practically unchanged.

Based on the scale of underperformance of investment programs in the previous period [10-13] and taking into account the low investment opportunities of the fuel and energy complex (due to low income from hydrocarbon exports), the most significant threat to Russia's ES until 2025 will be a lack of investment in the energy sector. This threat should be included in the list of threats under consideration.

The lack of investment affects the values of physical and obsolescence of production assets (PA). For example, in the gas industry the physical deterioration of the PA has exceeded $65 \%$, in the oil industry it has approached 55\%. With a lack of investment, the lag in the rate of replacement of morally and physically obsolete $\mathrm{PF}$ in the energy sector will continue. Therefore, this threat should also be included in the list of considered threats.

One of the reasons for the large share of obsolete PA in the Russian fuel and energy complex is the low rate of implementation of the best available technologies (BAT). The BAT requirements in various sectors of the fuel and energy complex of the country meet from 10 to $20 \%$ of PA (world practice - from 40 to $60 \%$ ) [14]. Accordingly, the threat of low rates of BAT implementation should also be included in the list of threats until 2025. Low rates of BAT implementation and the need to enter new, much more expensive oil production areas, along with the depletion of deposits in old regions, significantly increase the cost of this energy resource. According to $[15,16]$, the average break-even cost of Russian oil is $\$ 42-44$ per barrel. The factors of growth in the cost of Russian oil from year to year, with the expected relatively low world price for it $(60-70$ USD/bbl), oblige to include among the considered threats until 2025 the threat of reduced opportunities to increase oil production and export.

The threats under consideration should also include the threat of reducing the ability to maintain natural gas production. The main reason for this (in addition to the rapid decline in gas production at the old fields of the Nadym-Pur-Tazovsky region, where up to $85-90 \%$ of all Russian gas was produced $10-15$ years ago) is the obvious inexpediency of developing new (very expensive) gas production areas (shelf The Barents and Kara Seas, the Gydan Peninsula) due to the lack of prerequisites for a noticeable increase in gas prices in the future until 2035. The scale of this threat is reinforced by the facts of incorrect assessment of recoverable gas reserves at the Chayandinskoye and Kovykta fields in Eastern Siberia [2, 3, etc.].

The active implementation of this threat also requires consideration of the threat of natural gas domination in the FER balances of the regions of the European part of Russia and the Urals. At present, the share of gas in the domestic consumption of primary FER in the country remains at the level of $51-52 \%$ (Table 1). However, in a significant part of the mentioned regions, this share reaches $90-99 \%$. This situation is unacceptable due to a decrease in gas production opportunities in the country and due to difficulties with fuel and energy supply to consumers in the context of large-scale emergencies in the gas industry (the bulk of gas is produced in 2.5-3 thousand $\mathrm{km}$ from the places of its main consumption). At the same time, there are no peak UGS facilities designed to supply gas to the gas transmission network in emergency conditions in the UGSS system.

The character of the transformation of ES threats until 2025 and the factors determining this character are presented in Table. 2.

Judging by the data in the table 2 and taking into account the expected features of the functioning of the energy industries in 2026-2030 the threat of underinvestment in the energy sectors should be left for analysis. 
Table 2. The character of the transformation of the most significant threats to Russia's ES until 2025

\begin{tabular}{|c|c|c|c|c|}
\hline & ES threats & Amplifying factors & Weakening factors & $\begin{array}{c}\text { The } \\
\text { transformation } \\
\text { character }\end{array}$ \\
\hline 1 & $\begin{array}{l}\text { Lack of } \\
\text { investment in } \\
\text { energy } \\
\text { industries }\end{array}$ & $\begin{array}{l}\text { - accumulated problems with the financing; } \\
\text { - deterioration of reserves in old areas of oil and gas } \\
\text { production; } \\
\text { - the need to develop much more expensive areas of oil } \\
\text { and gas production; } \\
\text { - expected low income from hydrocarbon exports; } \\
\text { - a large role of the state in business management; } \\
\text { - unattractiveness of business (corruption, raiding); } \\
\text { - foreign economic sanctions }\end{array}$ & $\begin{array}{l}\text { - the expected increase in } \\
\text { hydrocarbon prices by } 2025 ; \\
\text { - lack of serious motivation to } \\
\text { increase the production of FER } \\
\text { (low prices on world markets, } \\
\text { low growth in domestic } \\
\text { demand); } \\
\text { - awareness of the need to } \\
\text { prioritize when planning energy } \\
\text { development }\end{array}$ & $\begin{array}{l}\text { Significant } \\
\text { increase }\end{array}$ \\
\hline 2 & $\begin{array}{l}\text { Low rates of } \\
\text { PA renewal in } \\
\text { energy } \\
\text { industries }\end{array}$ & $\begin{array}{l}\text { - lack of serious motivation to accelerate the } \\
\text { replacement of outdated PA (low growth rates of } \\
\text { domestic demand for FER); } \\
\text { - lack of investment; } \\
\text { - monopoly of FER suppliers; } \\
\text { - unattractiveness of business in Russia; } \\
\text { - foreign economic sanctions; } \\
\text { - unavailability of cheap loans; } \\
\text { - difficulties with the implementation of BAT }\end{array}$ & $\begin{array}{l}\text { - the need to ensure industrial } \\
\text { safety requirements; } \\
\text { - development of information } \\
\text { technologies with a } \\
\text { corresponding update in PA; } \\
\text { - increasing consumer } \\
\text { requirements for the FER } \\
\text { quality. }\end{array}$ & $\begin{array}{l}\text { Slight } \\
\text { increase }\end{array}$ \\
\hline 3 & $\begin{array}{l}\text { Low rates of } \\
\text { BAT } \\
\text { implementation } \\
\text { in energy } \\
\text { industries }\end{array}$ & $\begin{array}{l}\text { - lack of investment; } \\
\text { - great inertia in the development of energy industries; } \\
\text { - monopoly of FER manufacturers and suppliers; } \\
\text { - foreign economic sanctions; } \\
\text { - unattractiveness of business in Russia }\end{array}$ & $\begin{array}{l}\text { - stagnation of the economy; } \\
\text { - possible improvement of the } \\
\text { investment climate }\end{array}$ & $\begin{array}{l}\text { Slight } \\
\text { increase }\end{array}$ \\
\hline 4 & $\begin{array}{l}\text { Reduced } \\
\text { opportunities to } \\
\text { increase oil } \\
\text { production }\end{array}$ & $\begin{array}{l}\text { - depletion of currently developed oil fields; } \\
\text { - transition to new, more expensive areas of oil } \\
\text { production; } \\
\text { - expected relatively low prices for liquid } \\
\text { hydrocarbons. } \\
\text { - foreign economic sanctions, including the } \\
\text { introduction of BAT }\end{array}$ & $\begin{array}{l}\text { Expected } \\
\text { - increasing the depth of oil } \\
\text { refining at Russian refineries; } \\
\text { - increase in the share of oil } \\
\text { products in the structure of } \\
\text { export of liquid hydrocarbons }\end{array}$ & $\begin{array}{l}\text { Significant } \\
\text { increase }\end{array}$ \\
\hline 5 & $\begin{array}{l}\text { Reduced ability } \\
\text { to maintain } \\
\text { natural gas } \\
\text { production }\end{array}$ & $\begin{array}{l}\text { - rapid decline in production levels in the NPTR; } \\
\text { - inexpediency of the development of the gas shelf of } \\
\text { the Barents and Kara Seas (lack of investment, } \\
\text { increased competition and low prices in the world gas } \\
\text { markets, an increase in the share of renewable energy } \\
\text { sources in countries importing gas); } \\
\text { - growth in the prime cost of gas supplies. }\end{array}$ & $\begin{array}{l}\text { - stagnation of the Russian } \\
\text { economy with no growth in } \\
\text { FER demand; } \\
\text { - decrease in the possibilities of } \\
\text { exporting russian gas for } \\
\text { foreign economic and foreign } \\
\text { policy reasons. }\end{array}$ & $\begin{array}{l}\text { Significant } \\
\text { increase }\end{array}$ \\
\hline 6 & $\begin{array}{l}\text { Dominance of } \\
\text { natural gas in } \\
\text { the FER } \\
\text { balances of the } \\
\text { regions of the } \\
\text { European part } \\
\text { of Russia and } \\
\text { the Urals }\end{array}$ & $\begin{array}{l}\text { - great inertia in the development of the FEC; } \\
\text { - gas preference in terms of price-quality ratio; } \\
\text { - decrease in production volumes in old areas and the } \\
\text { need to develop new expensive areas; } \\
\text { - reduced opportunities to increase gas production } \\
\text { volumes; } \\
\text { - growth in the prime cost of gas supplies. }\end{array}$ & $\begin{array}{l}\text { - low growth of FER domestic } \\
\text { demand; } \\
\text { - the expected awareness of the } \\
\text { great negative significance of } \\
\text { this threat }\end{array}$ & $\begin{array}{l}\text { Slight } \\
\text { increase }\end{array}$ \\
\hline
\end{tabular}

Instead of two threats (low rate of replacement of PA and low rate of implementation of BAT) from 2026 to 2030 let us consider only one - the low rates of BAT implementation in the energy industries. Replacement of obsolete PA should mean, mainly, the introduction of BAT, and replacement of physically outdated PA should be mandatory even due to industrial safety requirements. Threats to reduce opportunities to increase oil production and maintain gas production from 2026 to 2030 should be considered already as threats to reduce oil and gas production levels. The decline in gas production levels makes it mandatory to consider the threat of gas domination in the European part of the country and in the Urals.
The results of assessing of the transformation character of the listed threats from 2026 to 2030 and the factors determining this character are presented in Table 3.

For the period 2031-2035, it is proposed to consider only those threats, the character of the transformation of which in the previous period (Table 3) was assessed as "a significant increase". The results of assessing the transformation of these threats in the specified period are presented in table 4 . 
Table 3. The character of the transformation of the most significant threats to Russia's ES from 2026 to 2030

\begin{tabular}{|c|c|c|c|c|}
\hline & ES threats & Amplifying factors & Weakening factors & $\begin{array}{c}\text { The } \\
\text { transformation } \\
\text { character }\end{array}$ \\
\hline 1 & $\begin{array}{l}\text { Lack of } \\
\text { investment in } \\
\text { energy } \\
\text { industries }\end{array}$ & $\begin{array}{l}\text { - expected growth of domestic demand for } \\
\text { FER; } \\
\text { - striving to retain Russia's share in external } \\
\text { markets for hydrocarbon sales in the } \\
\text { conditions of low prices; } \\
\text { - the need to increase investments to increase } \\
\text { the share of renewable energy }\end{array}$ & $\begin{array}{l}\text { Expected: } \\
\text { - improving the investment climate; } \\
\text { - diversification of the structure of } \\
\text { GDP; } \\
\text { - easing of foreign sanctions }\end{array}$ & $\begin{array}{c}\text { Slight } \\
\text { mitigation }\end{array}$ \\
\hline 2 & $\begin{array}{l}\text { Low rates of } \\
\text { BAT } \\
\text { implementation } \\
\text { in energy } \\
\text { industries }\end{array}$ & $\begin{array}{l}\text { - growing importance of factors: lack of } \\
\text { investment, inertia in the development of the } \\
\text { energy sector; } \\
\text { - technological development of energy in the } \\
\text { world, scientific and technological progress, } \\
\text { competition in energy markets }\end{array}$ & - expected easing of foreign sanctions & $\begin{array}{l}\text { Significant } \\
\text { increase }\end{array}$ \\
\hline 3 & $\begin{array}{l}\text { Decrease in oil } \\
\text { production }\end{array}$ & $\begin{array}{l}\text { - strengthening of factors: deterioration of oil } \\
\text { reserves; decrease in the competitiveness of } \\
\text { Russian oil on world markets decrease in the } \\
\text { growth of global demand for liquid } \\
\text { hydrocarbons }\end{array}$ & $\begin{array}{l}\text { - low annual growth in domestic } \\
\text { consumption of oil products; } \\
\text { - a significant difference between the } \\
\text { volume of oil production in the } \\
\text { country and the volume of its refinary }\end{array}$ & $\begin{array}{l}\text { Significant } \\
\text { increase }\end{array}$ \\
\hline 4 & $\begin{array}{l}\text { Decrease in gas } \\
\text { production }\end{array}$ & $\begin{array}{l}\text { - strengthening of factors: reduction of } \\
\text { production levels in old regions, high cost of } \\
\text { development of new regions, lack of } \\
\text { prerequisites for a noticeable rise in gas prices } \\
\text { on world markets; } \\
\text { - dominance of gas in the FER balances of the } \\
\text { country and some regions }\end{array}$ & $\begin{array}{l}\text { - the expected decrease in the } \\
\text { politicization of decisions on the } \\
\text { development of the gas industry }\end{array}$ & $\begin{array}{l}\text { Significant } \\
\text { increase }\end{array}$ \\
\hline & $\begin{array}{l}\text { Dominance of } \\
\text { natural gas in } \\
\text { the FER } \\
\text { balances of the } \\
\text { regions of the } \\
\text { European part } \\
\text { of Russia and } \\
\text { the Urals }\end{array}$ & $\begin{array}{l}\text { - inertia of changes in the structure of FER } \\
\text { balances within the country and regions; } \\
\text { - expected growth in demand for FER } \\
\text { (corresponding to the pace of economic } \\
\text { development); } \\
\text { - decrease in gas production }\end{array}$ & $\begin{array}{l}\text { Ожидаемые: } \\
\text { - weakening of the state role in the } \\
\text { development of the gas industry; } \\
\text { - transition to equal profitability of gas } \\
\text { in the external and internal markets; } \\
\text { - easing of foreign sanctions }\end{array}$ & $\begin{array}{l}\text { Significant } \\
\text { increase }\end{array}$ \\
\hline
\end{tabular}

Table 4. The character of the transformation of the most significant threats to Russia's ES from 2031 to 2035

\begin{tabular}{|c|c|c|c|c|}
\hline & ES threats & Amplifying factors & Weakening factors & $\begin{array}{c}\text { The } \\
\text { transformation } \\
\text { character }\end{array}$ \\
\hline 1 & $\begin{array}{l}\text { Low rates of } \\
\text { BAT } \\
\text { implementation } \\
\text { in energy } \\
\text { industries }\end{array}$ & $\begin{array}{l}\text { - lack of investment; } \\
\text { - the inertia of the FEC development; } \\
\text { - preservation of the great role of the state in } \\
\text { the field of energy management }\end{array}$ & $\begin{array}{l}\text { - change in the structure of the income } \\
\text { part of Russia's GDP with a decrease in } \\
\text { the dependence on the oil and gas } \\
\text { sector }\end{array}$ & $\begin{array}{l}\text { Slight } \\
\text { mitigation }\end{array}$ \\
\hline 2 & $\begin{array}{l}\text { Decrease in oil } \\
\text { production }\end{array}$ & $\begin{array}{l}\text { - the need to develop new expensive oil } \\
\text { production areas; } \\
\text { - lack of investment; } \\
\text { - insufficient rates of BAT implementation; } \\
\text { - lack of prerequisites for a noticeable increase } \\
\text { in world prices for oil and oil products }\end{array}$ & $\begin{array}{l}\text { - reducing the dependence of Russia's } \\
\text { GDP on the oil and gas sector; } \\
\text { - decrease in the volume of oil exports; } \\
\text { - no growth in domestic consumption of } \\
\text { oil products with an increase in the role } \\
\text { of electricity in transport }\end{array}$ & $\begin{array}{l}\text { Slight } \\
\text { mitigation }\end{array}$ \\
\hline 3 & $\begin{array}{l}\text { Decrease in gas } \\
\text { production }\end{array}$ & $\begin{array}{l}\text { - rapid decline in gas production in old areas, } \\
\text { - inexpediency of the development of the gas } \\
\text { shelf of the Barents, Kara and Okhotsk seas for } \\
\text { export purposes due to the high cost of } \\
\text { production, processing and transportation of } \\
\text { gas in the absence of prerequisites for a } \\
\text { significant increase in world gas prices; } \\
\text { - dominance of gas in the FER balance of the } \\
\text { country and some regions }\end{array}$ & $\begin{array}{l}\text { - a noticeable decrease in the growth rate } \\
\text { of gas demand in importing countries } \\
\text { associated with an increase in the share } \\
\text { of renewable energy sources in the } \\
\text { structures of FER balance }\end{array}$ & $\begin{array}{l}\text { Significant } \\
\text { increase }\end{array}$ \\
\hline 4 & $\begin{array}{l}\text { Dominance of } \\
\text { natural gas in } \\
\text { the FER } \\
\text { balances of the }\end{array}$ & $\begin{array}{l}\text { - inertia of changes in the structure of FER } \\
\text { balances within the country and regions; } \\
\text { - a noticeable decrease in gas production } \\
\text { volumes in old gas production areas; }\end{array}$ & $\begin{array}{l}\text { - the absence of prerequisites for an } \\
\text { increase in world prices for gas and the } \\
\text { high cost of its production and transport } \\
\text { cause the inexpediency of its export; }\end{array}$ & $\begin{array}{l}\text { Slight } \\
\text { increase }\end{array}$ \\
\hline
\end{tabular}




\begin{tabular}{|l|l|l|l|l|}
\hline $\begin{array}{l}\text { regions of the } \\
\text { European part } \\
\text { of Russia and } \\
\text { the Urals }\end{array}$ & $\begin{array}{l}\text { - lack of investment for the development of } \\
\text { new expensive gas production areas (gas shelf } \\
\text { of the Barents, Kara and Okhotsk seas) }\end{array}$ & $\begin{array}{l}\text { - change in the structure of GDP in the } \\
\text { direction of growth of non-energy- } \\
\text { intensive, knowledge-intensive } \\
\text { industries with limited growth of the } \\
\text { country's internal energy needs }\end{array}$ & \\
\hline
\end{tabular}

\section{Expected opportunities to meet Russia's internal needs for primary FER in the considered perspective}

\subsection{Possible internal needs for primary FER}

The total annual domestic needs of the country for primary FER can be logically determined as $Q_{t}=Q_{t-1}\left(1+K_{G D P}^{t}-K_{i n}^{t}\right)$, where $Q_{t-1}$ is the volume of consumption of these FER in $(t-1)$ year; $K_{G D P}^{t}$ and $K_{i n}^{t}$ are the coefficients of change in Russia's GDP and the specific energy intensity of GDP in $t$ year relative to $(t-$ 1) year. When determining internal needs for primary FER, the following average annual values were taken for $K_{G D P}^{t}$ and $K_{\text {in }}^{t}$, Table 5 .

Table 5. Assumed coefficients of change in Russia's GDP and specific energy intensity of GDP for the perspective up to 2035

\begin{tabular}{|c|c|c|}
\hline Time period & $K_{G D P}^{t}$ & $K_{\text {in }}^{t}$ \\
\hline $2020-2025$ & $0,015-0,017$ & $0,005-0,010$ \\
\hline $2026-2030$ & $0,020-0,025$ & $0,010-0,015$ \\
\hline $2031-2035$ & $0,025-0,035$ & $0,020-0,025$ \\
\hline
\end{tabular}

Taking into account the impact of the COVID-19 pandemic on the Russian economy in 2020, it is possible to assume a decrease in GDP compared to 2019. At the same time, when the economy exits the conditions of the pandemic in 2021, it can be assumed that the recovery rate will be slightly increased with the achievement of the targets outlined earlier. Accordingly, in 2020 we propose the value of the country's internal needs for primary FER to be considered approximately equal to 2019 (1057 mln tce), and then follow the values of the indicators presented in Table 5. Then it can be assumed that in 2025 this value will be at the level of 1090-1110, in 2030 - 1150-1170 and in $2035-1180-1230 \mathrm{mln}$ tce.

\subsection{Production capabilities of Russia's energy industries}

\subsubsection{Russia's oil industry prospects}

In 2018 and 2019, the consumption of oil products in the country together with oil used directly was 231 and 228 million tons of fuel equivalent, respectively (taking into account [15]). From 2020 to 2035, domestic demand for light petroleum products will grow by no more than 0.5 $1 \%$ per year due to the expected active increase in the share of electric transport. The volume of oil directly flared will decrease. Accordingly, the total volume of petroleum products and crude oil used within the country should not increase until 2035, but it will not decrease significantly either. We will assume that in 2020 it will remain approximately at the level of 2019 - about 230 mln tce, in 2025 it will be 220-230, in 2030 - 215-225 and in $2035-210-220 \mathrm{mln}$ tce. These volumes are much less than the volumes of liquid hydrocarbon production today (in $2019-560 \mathrm{mln}$ t or $790 \mathrm{mln}$ tce). Apparently, such an excess of production volumes over domestic consumption may persist until 2035. The possibilities for increasing oil production in the country will most likely be exhausted by 2025 (Table 2). In 2020, oil production in Russia could amount to approximately $560-565 \mathrm{mln}$ t. At the same time, according to the "OPEC +" deal, during the period of reduction in oil prices in the world in 2020, oil production will probably be at the level of 500-510 mln t. This recession should lead to some revival of the world economy, perhaps the previous level of oil production (550-560 million tons) will be restored by 2025 . Outside 2025 , we should expect a decrease in oil production to $500-520 \mathrm{mln} \mathrm{t}$ in 2030 and up to 400 $450 \mathrm{mln} \mathrm{t}$ by 2035 .

\subsubsection{Russia's coal industry prospects}

Annual levels of coal consumption in the country have been declining over the past 5 years. From 2020 to 2025, due to a reduction in opportunities to increase gas production in the country, the possibilities for replacing coal-fired electricity and heat generating capacities with gas ones will also be exhausted. Accordingly, if from 2020 to 2025 one can expect a slow but decrease in the volume of coal consumption, then after 2025 its consumption should grow slightly (by $0.3-0.5 \%$ per year). This will slightly neutralize the threat of gas dominance. Accordingly, domestic consumption of coal will be: in 2020 - 185-190, in 2025 - 180-190, in 2030 185-195, and in $2035-200-210 \mathrm{mln} \mathrm{t}$ against $191 \mathrm{mln} \mathrm{t}$ in 2019 The volumes of Russian coal exports (taking into account the growing competition on world markets) are likely to decrease slightly and will be approximately as follows: 2020 - 190-200, 2025 - 180-190, 2030 - 170190, 2035. - 160-180 mln t.

\subsubsection{Nuclear-, hydropower plants and other renewable sources}

The total production volumes of primary FER in Russia at hydroelectric power plants, nuclear power plants and other sources have changed insignificantly in recent years. In terms of the volume of hydrocarbon fuel for generating the same amount of electricity at TPPs in 2019, these volumes amounted to $166 \mathrm{mln}$ tce. Taking into account a slight increase in the share of nontraditional FER and electricity production at hydroelectric and nuclear power plants, the indicated volumes can be $165-170$ in 2020, 180-190 - in 2025, 190-210 - in 2030 and 220-250 mln tce in 2035. 


\subsubsection{Assessment of the possibilities of meeting the internal needs of Russia in primary FER with the formation of requirements for the gas industry}

The aforementioned about the coverage of the expected domestic demand in Russia for primary FER for all reference years from all energy industries except the gas industry is reflected in Table 6 . The same table shows the requirements for the country's gas industry to cover the specified total needs for primary FER.

Table 6. Expected opportunities to meet Russia's internal needs for primary FER with the formation of requirements for the gas industry*

\begin{tabular}{|c|c|c|c|c|c|}
\hline Index & 2019 & 2020 & 2025 & 2030 & 2035 \\
\hline $\begin{array}{l}\text { Internal needs for } \\
\text { primary FER, mln tce }\end{array}$ & 1057 & 1060 & 1100 & 1160 & 1210 \\
\hline \multicolumn{6}{|l|}{ Covering by } \\
\hline Oil industry, mln tce & 228 & 230 & 225 & 220 & 215 \\
\hline Coal industry, mln tce & 124 & 120 & 120 & 125 & 130 \\
\hline $\begin{array}{r}\text { Nuclear-, hydropower } \\
\text { plants and other } \\
\text { renew., mln tce }\end{array}$ & 166 & 170 & 185 & 200 & 230 \\
\hline Requirements for the & & & & & \\
\hline Gas industry, mln tce & 539 & 540 & 570 & 615 & 635 \\
\hline $\mathrm{bcm}$ & 469 & 470 & 495 & 535 & 550 \\
\hline
\end{tabular}

* Average values of respective ranges are used.

In Table 6, we have identified the requirements for gas volumes to cover the Russia's domestic needs for primary FER. Now let's consider the possibilities of the gas industry to ensure these volumes. We will also consider the possibilities (taking into account the planned imports) to ensure the export of Russian gas for the same perspective.

\subsubsection{Russia's gas industry prospects, taking into account the requirements of possible gas exports}

Gas imports to Russia in 2019 amounted to $9 \mathrm{bcm}$ [17]. Until 2035, it is unlikely to exceed $10 \mathrm{bcm} /$ year. When assessing the levels of gas production (both natural and associated), we should take into account the following points:

1. Decrease in opportunities to increase gas production until 2025 and decrease in gas production after 2025 (judging by the character of the transformation of threats to Russia's ES).

2. Low world gas prices in 2020 and the absence of prerequisites for a noticeable increase until 2035 with an increase in the average cost of gas production and transportation and a high cost of Russian LNG production.

3. By the beginning of 2021 , the decline in gas prices will probably stop and this price will most likely stabilize until 2035 (in the absence of prerequisites for a noticeable increase). The price range for European countries can be 200-230 USD $/ \mathrm{mmcm}$. How far these prices will differ from the cost of Russian gas from new regions of its production on the border with Germany can be estimated from the data in Table 7. At the same time, under the cost of gas, in contrast to only operating costs $[18$, etc.], we mean the ratio of the sum of all capital and operating costs associated with the development of a gas field during the entire development and operation of the field to the total volume of gas production during this time. The same approach is applicable to the calculation of the cost of gas transportation to delivery points.

Table 7. Expected cost of Russian gas from new regions of its production on the border with Germany*

\begin{tabular}{|c|c|c|c|c|}
\hline \multirow{2}{*}{$\begin{array}{l}\text { Production area, } \\
\text { method of } \\
\text { development }\end{array}$} & \multicolumn{4}{|c|}{ Cost, USD/mmcm } \\
\hline & 2020 & 2025 & 2030 & 2035 \\
\hline $\begin{array}{l}\text { Yamal (operat. } \\
\text { fields): } \\
\text { pipeline gas } \\
\text { LNG }\end{array}$ & $\begin{array}{l}150-170 \\
180-190\end{array}$ & $\begin{array}{l}160-180 \\
190-210\end{array}$ & $\mid \begin{array}{l}170-190 \\
200-220\end{array}$ & $\begin{array}{c}170-190 \\
200-220\end{array}$ \\
\hline $\begin{array}{l}\text { Yamal (new } \\
\text { fields) } \\
\text { pipeline gas } \\
\text { LNG }\end{array}$ & $\begin{array}{l}170-190 \\
200-210\end{array}$ & $\begin{array}{l}210-230 \\
240-260\end{array}$ & $\begin{array}{l}240-270 \\
260-290\end{array}$ & $\begin{array}{l}240-270 \\
260-290\end{array}$ \\
\hline $\begin{array}{l}\text { Shelf of the } \\
\text { Kara Sea (under } \\
\text { development) } \\
\text { pipeline gas }\end{array}$ & & $290-320$ & $340-380$ & $340-380$ \\
\hline $\begin{array}{l}\text { Gydan } \\
\text { peninsula } \\
\text { (under } \\
\text { development), } \\
\text { pipeline gas }\end{array}$ & & $240-280$ & $280-300$ & $280-300$ \\
\hline
\end{tabular}

Estimation of the authors [19, etc.].

4. Comparison of the expected world gas prices with the data in Table 7 indicates that there is no economic feasibility of developing gas fields on the Gydan Peninsula and on the shelf of the Kara Sea for export purposes (at least until 2035). Due to the unresolved nature of a number of fundamental technical issues and the same expected low gas prices until 2035, the development of the Shtokman field (shelf of the Barents Sea) cannot be expected.

5. Gas production growth rates in Yamal will not be as high as in 2018-2019 (26 bcm) - LNG production capacities were being increased. Production growth rates will be constrained by low world gas prices. According to the authors' estimates, this increase will not exceed 2$3 \mathrm{bcm} /$ year by 2025 . Outside 2025 (up to 2035) - after the development of the Kharasaveyskoye field, the increase in production in Yamal will increase again, but only within the range of 5-6 bcm/year.

6. The Chayandinskoye (Yakutia) and Kovyktinskoye (Irkutsk Region) fields will be developed with gas production here in $2020-1-2 \mathrm{bcm}$, and by $2025-20-40$ $\mathrm{bcm} /$ year (currently there is uncertainty with the confirmed gas reserves for these fields [2, 3, etc.]).

7. Due to the lack of investment, it is difficult to expect a noticeable increase in gas production on Sakhalin and the shelf of the Sea of Okhotsk until 2035.

8 . The decrease in gas production in NPTR will continue (on average, in recent years, production has fallen by 16 $\mathrm{bcm} /$ year). 
9. By 2030, a slight decrease in oil production will lead to a decrease in the production of associated gas (from $100 \mathrm{bcm}$ in 2019 to $80-90 \mathrm{bcm}$ by 2035).

Taking into account the data in Table 6 and the reasoning given above, Table 8 was formed, which presents the situation with the balance of Russian gas expected until 2035. The incoming part of this table takes into account the possibilities of the main gasbearing regions and imports. The actual figures for recent years are also given here.

Table 8. Actual and expected up to 2035 values of the Russia's gas balance (total natural and associated gas), bcm

\begin{tabular}{|c|c|c|c|c|c|c|}
\hline \multirow{2}{*}{ Index } & \multicolumn{2}{|c|}{ Actually } & \multicolumn{4}{|c|}{ Forecast } \\
\hline & 2017 & 2019 & 2020 & 2025 & 2030 & 2035 \\
\hline $\begin{array}{l}\text { Gas production (natural and associated), } \\
\text { incl. }\end{array}$ & 691 & 736 & 730 & 720 & 690 & 630 \\
\hline Nadym-Pur-Tazovsky region & 468 & 436 & $420-425$ & $350-370$ & $280-310$ & $200-240$ \\
\hline Yamal Peninsula & 75 & 101 & $105-110$ & $120-140$ & $160-190$ & $180-220$ \\
\hline European part of Russia & 51 & 59 & $60-65$ & $60-70$ & $60-70$ & $50-60$ \\
\hline Tomsk region, Eastern Siberia & 22 & 28 & $28-30$ & $45-50$ & $50-60$ & $50-60$ \\
\hline $\begin{array}{r}\text { Ob-Taz Bay and Bolshekhetskaya } \\
\text { Depression }\end{array}$ & 40 & 68 & $60-65$ & $60-65$ & $40-60$ & $30-50$ \\
\hline Far East & 35 & 44 & $45-50$ & $50-60$ & $50-60$ & $50-60$ \\
\hline Imports & 9 & 9 & 10 & 10 & 10 & 10 \\
\hline Available volumes* & 700 & 745 & 740 & 730 & 700 & 640 \\
\hline $\begin{array}{l}\text { The required volume of gas to cover } \\
\text { internal needs for primary FER }\end{array}$ & 469 & 469 & 470 & 495 & 535 & 550 \\
\hline Technical capabilities of gas export & 231 & 276 & 270 & 235 & 165 & 90 \\
\hline
\end{tabular}

Sum of average values of ranges of possibilities.

As can be seen from the data in Table 8, the capabilities of the Russian gas industry, taking into account the small volumes of imports, fully cover the gas requirements to meet the country's internal needs for primary FER. At the same time, the technical (excluding the situation on the world gas markets) opportunities for the export of Russian gas are significantly reduced.

\section{Conclusion}

Real quantitative indicators of the functioning of the Russian fuel and energy complex in 2014-2019, as well as the results of assessing the character of the transformation of the most significant threats to the Russia's ES until 2035, made it possible to assess the available capabilities of its energy industries to meet the country's internal needs for primary FER. The technical capabilities for the export of Russian gas for the period up to 2035 were also assessed. The paper showed that by 2035 the total annual capabilities of the country's fuel and energy complex for the production of primary FER together with the import of FER to Russia will exceed its internal needs. A decrease in oil production will also not affect the provision of domestic needs of the country with petroleum products. At the same time, by 2035, we should expect a reduction in the possibilities for the export of FER from 1,049 $\mathrm{mln}$ tce up to 700-800 $\mathrm{mln}$ tce. Opportunities for the export of Russian gas, provided that the country's internal needs are met without deficits, will noticeably decrease (from $276 \mathrm{bcm}$ in 2019 to $90 \mathrm{bcm} /$ year by 2035).

The decline in the possibilities for the production and export of hydrocarbons is accompanied by the absence of prerequisites for a significant increase in world prices for them until 2035. In the same period, an increase in the share of non-traditional types of FER in the energy balances of countries importing hydrocarbons is expected. Accordingly, competition among hydrocarbon exporting countries will intensify. All these processes will coincide with the steady increase in the average cost of oil and gas production and transportation in Russia due to the depletion of reserves in most of the currently operating production areas and the need to develop new very expensive oil and gas production areas.

There can be only one direction of measures to improve the situation: a rapid change in the structure of the Russian economy towards an increase in the share of science-intensive and low-energy-intensive spheres of activity with the release of competitive products with high added value. The possibilities for the development of the Russian economy through the sale of natural hydrocarbons for the near future have been exhausted.

The work was carried out within the framework of a scientific project III.17.5.1 of program of fundamental research of the SB RAS, reg. number AAAA-A17-117030310451-0 and RFBR grant No. 20-08-00367.

\section{References}

1. http://publication.pravo.gov.ru/Document/View/0001 201905140010 ? index $=0$ \& rangeSize $=1$

2. European Union Natural Gas Import Price / https://ycharts.com/indicators/europe_natural_gas_pr ice

3. https://www.gazeta.ru/business/2020/05/28/1309908 7.shtml

4. https://vz.ru/news/2020/5/28/1041817.html

5. Analytical tables. InfoTEK [Fuel Energy Sector Info], 1, 102-121 (2015).

6. Analytical tables. InfoTEK [Fuel Energy Sector Info], 1, 109-126 (2017).

7. Analytical tables. InfoTEK [Fuel Energy Sector Info], 1, 100-117 (2019). 
8. Analytical tables. InfoTEK [Fuel Energy Sector Info], 1, 88-106 (2020).

9. Oil Price Charts / https://oilprice.com/oil-price-charts

10. http://atominfo.ru/newso/v0911.htm

11. http://www.finanz.ru/novosti/aktsii/obem-investiciyv-neftegazovuyu-otrasl-rf-v-2016-g-sokhranitsya-naurovne-2015-g-novak-1001256417

12. http://special.tass.ru/tek/3821851

13. http://www.ngv.ru/news/kapitalnye_investitsii neftyanykh_kompaniy_rf_vyrastut_v_2016_g_na_10 do_1_19 trln_rub/?sphrase id $=\overline{5} 7 \overline{2} 4968$

14. $\bar{Y}$ u. A. Stankevich, Energet. politika [Ener. Policy], 1, 123-128 (2017).

15. https://www.bbc.com/russian/news-50392407

16. https://energybase.ru/news/industry/cost-of-oilproduction-in-russia-exceeds-40-per-barrel-2019-1112

17. https://www.kommersant.ru/doc/4019560

18. http://www.finmarket.ru/shares/analytics/5212111

19. V.I. Rabchuk, S.M. Senderov, ECO vseros. ekon. jurn. [ECO Rus. Econ. Journ.], 8, 19-30 (2013). 